\title{
Changes in Serum Proteins and Protein-Bound Carbohydrates in Diabetes Mellitus*
}

\author{
Dovald E. MoMiluan
}

\author{
Sansum Clinic Research Foundation, Santa Barbara, California, and U.S. Public Health Service Hospital, San Fran- \\ cisco, California, USA
}

Received: January 24, 1970

\begin{abstract}
Summary. Studies of serum proteins and proteinbound carbohydrates were carried out on twenty-one diabetics without proteinuria and twenty controls. The diabeties had depression of serum total protein and albumin levels, and elevation of levels of all four types of protein-bound carbohydrate. The degree of elevation was greatest for fucose and least for sialic acid. When the diabetic group was divided into patients with and without evidence of retinopathy or neuropathy, the only significant difference found was an increase of alpha 2 -globulin in diabetics with these sequelae. Alpha 2-globulin levels were found to be correlated with both fasting plasma glucose and duration of diabetes. Alpha 2-macroglobulin levels were elevated equally in diabeties with and without sequelae, and appeared related to atherosclerosis rather than to diabetes mellitus. Although disorders other than diabetes increase the magnitude of protein-bound carbohydrate elevation seen, their presence or absence has little influence on the fucose-dominated pattern of elevation found.
\end{abstract}

Modifications des protéines sériques et des hydrates de carbone liés aux protéines dans le diabète sucré

Résumé. L'auteur a étudié les protéines sériques et les hydrates de carbone liés aux protéines chez 21 diabétiques sans albuminurie et chez 20 sujets témoins. Il a observé un abaissement du taux des protéines et albumines sériques et une élevation du taux des quatre types d'hydra. tes de carbone liés aux protéines. Le taux le plus élevé fut observé pour le fucose, et le moins élevé pour l'acide sialique. Si le groupe des diabétiques est divisé entre sujets avec ou sans rétinopathie ou neuropathie, la seule différence notable fut une élévation de la globuline alpha-2 chez les diabétiques présentant ces complications. Les taux de la globuline alpha-2 furent en rapport avec le niveau du glucose plasmatique à jeun, ainsi qu avec la durée du diabète. Les taux de macroglobuline alpha-2 présentèrent une élevation semblable chez les sujets avec ou sans complications, et parurent en rapport avec l'athérosclérose plutôt qu'avec le diabète. Bien que d'autres états non diabétiques augmentent le degré d'élévation des hydrates de carbone liés aux protéines, leur présence ou absence a peu d'influence sur le caractère de l'élévation où le fucose prédomine.

Veränderungen der Serumeiweißkörper und der proteingebundenen Kohlenhydrate bei Diabetes mellitus

Zusammenfassung. Die Serumspiegel von Proteinen und an Proteine gebundene Kohlenhydrate wurden bei einundzwanzig Diabetikern ohne Proteinurie und zwanzig Kontrollen ermittelt. Die Diabetiker hatten niedrige Werte für Gesamt-Protein und Albumin, erhöhte Werte für alle vier Typen der Protein-gebundenen Kohlenhydrate. Der Fucose-Spiegel war am meisten, der Acetylneuraminsäure-Spiegel am wenigsten erhöht. Nach Ünterteilung der Diabetiker in solche mit oder ohne Nebenerscheinungen von Retinopathie und Neuropathie wurde bei den ersteren eine Erhöhung des Alpha 2-GlobulinSpiegels als einziger signifikanter Unterschied festgestellt. Der Serumspiegel des Alpha 2-Globulins stand in Wechselbeziehung mit dem Blutzuckerspiegel und der Dauer des Dizubetes. Die Serumspiegel der Alpha 2-Makroglobuline waren erhöht bei den Diabotikern mit oder ohne Neben. erscheinungen; diese Erhöhungen waren anscheinend mehr von der Atherosklerose als vom Diabetes mellitus abhängig. Während die Nebenkrankheiten des Diabetes das Ausmaß der Erhöhung des Serumspiegels von Protein-gebundenen Kohlenhydraten beeinflußten, blieb die dominierende Erhöhung der Fucose unverändert.

Key-words: Blood proteins, glycoproteins, fucose, neuraminic acids (sialic acid), hexose, hexosamine, serum albumin, serum globulins.

\section{Introduction}

Although principal attention has been addressed to disturbances in the glucose content of blood in diabetes mellitus, an associated elevation of protein-bound carbohydrate was noted even before the isolation of insulin [6]. A considerable number of studies of serum proteins and protein-bound carbohydrates have been reported since, and most have been reviewed by Winzler [46]. In general they have demonstrated a decrease in serum albumin, an increase in alpha 2-globulin, and an increase in protein-bound hexose, hexosamine, and sialic acid in diabetes mellitus, especially in the presence of diabetic retinopathy or

* Some of the material reported here was initially published in abstract form in Clinical Research 16, 129, 1968. other evidence of small blood vessel disease. Serum protein-bound fucose has been found to be normal in diabetes in one reported study [31], whereas total plasma "fucose" has been reported to be elevated in diabetes in another study [37]. The characteristic abnormality in diabetic capillaries is apparently secondary to an increase in glycoprotein content $[29,39]$ of the vessel walls, but Winzler [46], on the basis of available information, has concluded that the serum protein and protein-bound carbohydrate changes reflect a reaction of the host to the disease and its complications rather than a product of the blood vessels themselves. One protein-bound carbohydrate, sialic acid, has been reported as elevated in potential diabetics [10], suggesting that some glycoprotein disturbance may precede rather than follow the development of overt diabetes. 
Prior studies of serum proteins and protein-bound carbohydrates have left a number of problems unresolved. No prior study has evaluated all four types of protein-bound carbohydrate and serum protein elements in the subjects, and the importance of certain characteristics of the diabetics studied required further confirmation. The results of this further examination or the problem reported below, demonstrate an unusual pattern of protein-bound carbohydrate elevation in diabetics which is not clearly dependent on the degree of duration of disturbance of carbohydrate metabolism. The changes seen are not explained by current knowledge of serum glycoproteins. The pattern of protein-bound carbohydrate may be a newly recognized characteristic of the diabetic state.

\section{Materials and Methods}

Diabetic subjects were ambulatory hospitalized patients who were not admitted for infectious disease, who had no temperature elevation during admission and no proteinuria. The presence or absence of retinopathy or neuropathy was determined by specific examination by the investigator one day before venesection. The diagnosis of diabetes mellitus had been made from blood and urine tests before study. The duration of diabetes was recorded as that reported by the subject, usually confirmed by examination of his medical record. Detection of glycosuria on routine physical examination was the typical initial event. The diagnosis of atherosclerosis was based on a diagnostic electrocardiogram and/or well defined history of myocardial infarction or the presence of advanced occlusive arterial disease. Blood pressure, and sedimentation rate (Wintrobe) were those recorded on admission. Control subjects were medical and technical personnel and other healthy individuals who were non-obese (less than $20 \%$ above ideal body weight) and had no known blood relatives with diabetes mellitus. Serum obtained from both groups was stored at $-22^{\circ} \mathrm{C}$ until examined. All determinations were performed in duplicate. Total protein was determined by the biuret method of Kingsley [25] using a Versatol standard. Plasma glucose was determined by the glucose oxidase method. Electrophoresis of 0.5 microliter of serum was carried out on $2.5 \times 16 \mathrm{~cm}$ cellulose acetate strips. The strips were stained using standard Ponceau S [32] technique. Scanning of the strips was done on a Photovolt densitometer, and a correction factor of 0.8 was used to compensate for increased stainability of serum albumin, so that the albumin content of the normal controls was comparable with values found by salt fractionation techniques [48].

Protein-bound glucosamine was determined using the Levry and McAllen technique [27] on alcohol precipitates of serum after hydrolysis with $3 \mathrm{~N}$ HCL. Sialic acid was determined by the method of Warren [44] after hydrolysis at $80^{\circ} \mathrm{C}$ in $0.1 \mathrm{~N}$ sulphuric acid for one hour [42]. Protein-bound fucose and hexose were de- termined by a new method used to circumvent problems already cited [28]. The method, to be reported more fully later, combines the technique of Dische and Shettles [14] using cysteine to develop a colour with 6-deoxyhexose (fucose) in sulphuric acid at $399 \mathrm{~nm}$ and the phenol-hexose reaction [16] substituting o-cresol to produce a colour from hexose at $525 \mathrm{~nm}$ (peak 505 $\mathrm{nm}$ ). Conditions for formation of the chromogens were changed to reduce the fucose-like colour produced by galactose when amino acids are present in excess. After alcohol precipitation and washing of protein from $0.1 \mathrm{ml}$ of serum and solubilization in $0.8 \mathrm{ml} 0.1 \mathrm{~N}$ $\mathrm{NaOH}, 4.5 \mathrm{ml}$ of $8: 1 \mathrm{H}_{2} \mathrm{SO}_{4}: \mathrm{H}_{2} \mathrm{O}$ was added slowly with constant cooling in an ice bath. After warming to $22^{\circ} \mathrm{C}$ the mixture was then heated at $65^{\circ} \mathrm{C}$ in a water bath for $35 \mathrm{~min}$, cooled at $22^{\circ} \mathrm{C}$ for $15 \mathrm{~min}$ and $0.2 \mathrm{ml}$ of $0.1 \%$ alkali-washed redistilled o-cresol (Matheson, Coleman and Bell) added. After $30 \mathrm{~min}$ more, $0.1 \mathrm{ml}$ of $6 \%$ cysteine (Calbiochem) was added. The tubes were then allowed to stand in the dark overnight for full colour development [22]. The solutions were read in $1 \mathrm{~cm}$ cuvettes on a Hitachi Perkin-Elmer spectrophotometer at three wavelengths 399,430 , and $525 \mathrm{~nm}$. Fucose was calculated as described by Dische and Shettles [14], and hexose determined by comparing the $525 \mathrm{~nm}$ reading with a 100 microgram standard containing equal amounts of galactose and mannose. Under the above conditions, a solution of the hexose standard and $0.1 \mathrm{ml}$ of $4 \%$ bovine plasma albumin gives equal readings at 399 and $430 \mathrm{~nm}$. O-cresol is used rather than phenol for two reasons. It reacts only mildly with 6-deoxyhexose chromogen while giving maximum colour with hexose. Also the colour formed by the reaction of o-cresol with hexose is very close to that of tryptophan and hexose since tryptophan is apparently hydrolyzed in the acid to form an ortho substituted phenol. The method has an additional advantage, since added glucose reduces rather than increases the fucose level found.

Alpha 2-macroglobulin levels were kindly determined on twenty of the diabetics by Keith James. They were reported previously by James, Johnson, and Fudenberg [23].

Statistical analyses were carried out using standard techniques and tables [13].

\section{Results}

Twenty-one diabetics who had both electrophoretic and protein-bound carbohydrate analyses carried out on their serum were included in the study. Their mean age was 59.4 years (range $44-71$ years). On examination eleven were found to have no evidence of diabetic retinopathy or neuropathy. Ten others had clinically evident sequelae. Nine had retinopathy ranging from mild to far-advanced, the tenth having advanced neuropathy only. The mean age of the two groups was the same (59.4 years) but the reported duration of diabetes was 6.6 years in the diabetic without sequelae (range $0-15$ years) and 15.5 years in those with sequelae 
(4-24 years). All were male except for two females in the group without sequelae. All had maturity-onset diabetes and only three, all with sequelae, required insulin treatment. Three diabetics required only dietary management, nine were being treated with a sulphonylurea alone, and six with a sulphonylurea and biguanide. significantly higher in those with sequelae, the mean value for those without sequelae being almost identical with the control mean. The albumin level was lower in the group with sequelae, but the difference was not statistically significant. The alpha $1-$, beta-, and gamma-globulin values were similar. The protein-bound carbohydrate values were generally higher in the group

Table 1. Comparison of serum protein electrophoretic component and protein-bound carbohydrate levels in the control and diabetic groups

\begin{tabular}{|c|c|c|c|c|c|}
\hline & $\begin{array}{l}\text { Normal Controls } \\
\mathrm{N}=20\end{array}$ & $\begin{array}{l}\text { Diabetics } \\
\mathrm{N}=21\end{array}$ & Diff. & $t$ & $P$ \\
\hline Total Proteina & $7.09 \pm 0.26$ & $6.61 \pm 0.43$ & -0.48 & 4.3 & $<0.001$ \\
\hline Albumin ${ }^{2}$ & $3.81+0.37$ & $3.27+0.53$ & -0.54 & 3.8 & $<0.001$ \\
\hline Alpha 1-Globulina & $0.26 \pm 0.08$ & $0.23 \pm 0.07$ & -0.03 & 1.2 & N.S. \\
\hline Alpha 2-Globulina & $0.75 \div 0.14$ & $0.82 \pm 0.13$ & +0.07 & 1.6 & N.S. \\
\hline Beta-Globulina & $0.86 \pm 0.10$ & $0.84 \pm 0.13$ & -0.02 & 0.6 & N.S. \\
\hline Gamma-Globulina & $1.39 \pm 0.27$ & $1.45 \pm 0.41$ & +0.06 & 0.6 & N.S. \\
\hline Hexoseb & $104.7 \pm 13.3$ & $123.2 \pm 18.5$ & +18.5 & 3.6 & $<0.001$ \\
\hline Glucosamine $^{b}$ & $78.8 \pm 8.6$ & $93.1 \pm 12.3$ & +14.3 & 4.3 & $<0.001$ \\
\hline Sialic Acid ${ }^{b}$ & $61.1+10.1$ & $69.8 \pm 9,6$ & $\begin{array}{r}+8.7 \\
+\quad 8.7\end{array}$ & 2.8 & $<0.01$ \\
\hline Fucoseb & $12.4 \pm 1.5$ & 15.9 土 2.8 & $\begin{array}{r}+3.5 \\
+\end{array}$ & 5.0 & $<0.001$ \\
\hline
\end{tabular}

Figures given are mean \pm standard deviation $(\bar{x} \pm s)$. The difference is negative if the mean of the diabetic group is lower than the control group mean, and positive if higher. a $\mathrm{g} / 100 \mathrm{ml}$

$\mathrm{b} \mathrm{mg} / 100 \mathrm{ml}$

Table 2. Comparison of diabetics with and without sequelae for various serum parameters

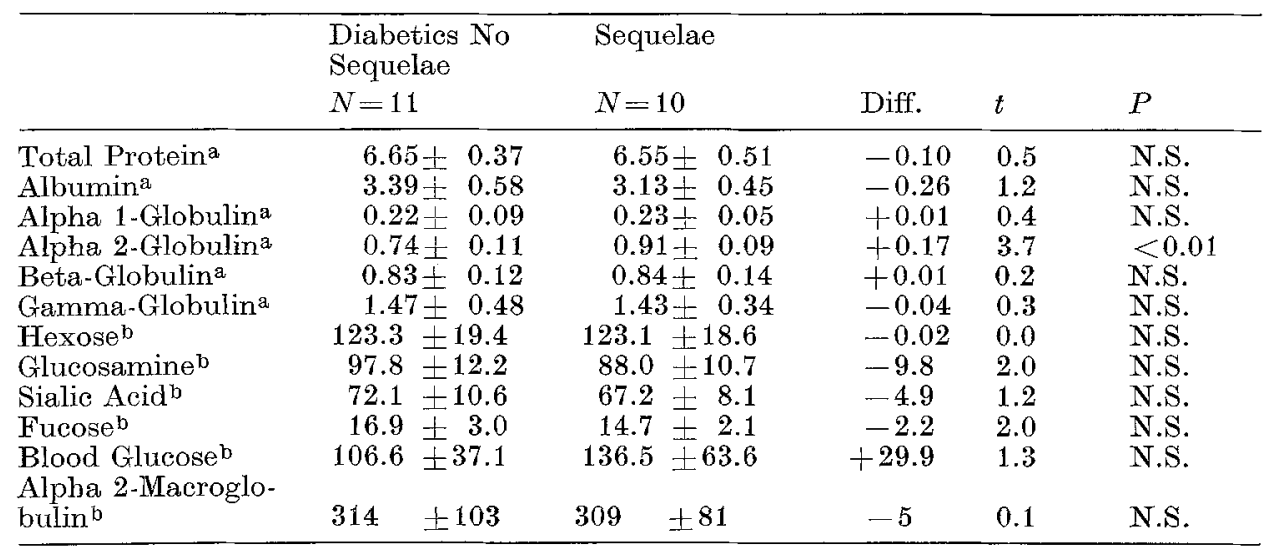

Figures given are mean \pm standard deviation $(\bar{x} \pm s)$. The difference is negative if the mean of diabeties with sequelae is lower than the mean of the diabetics without sequelae, and positive if higher.

$$
\begin{aligned}
& \mathrm{a} \mathrm{g} / 100 \mathrm{ml} \\
& \mathrm{b} \mathrm{mg} / 100 \mathrm{ml}
\end{aligned}
$$

The mean values and variations of the diabetic and control subjects are seen in Table 1 . Total protein and albumin values were lower in the diabetics and all protein-bound carbohydrate values higher. The alpha 1-, beta-, and gamma-globulin fractions did not differ and the alpha 2-globulin increase was not statistically significant. Although the mean gamma-globulin values did not differ, it should be noted that the standard deviation was much higher in the diabetic group $(F=$ 2.24, $P<0.05$ ).

When the two groups of diabetics were compared with each other (Table 2) the alpha 2-globulin was without sequelae, without statistically significant difference. Blood sugar levels were somewhat higher in the diabetics with sequelae. Alpha 2-macroglobulin levels were mildly elevated in both groups, normal for males being $265 \pm 55 \mathrm{mg} / 100 \mathrm{ml}$ [23]. The diabetics with and without sequelae seem quite comparable since two females were included in the former group and females have higher alpha 2-macroglobulin values (335 $\pm 55 \mathrm{mg} / 100 \mathrm{ml}$ ) [23].

Fig. 1 illustrates the distribution of the various protein-bound carbohydrates in the normal and diabetic subjects. Each value is expressed as percent above 

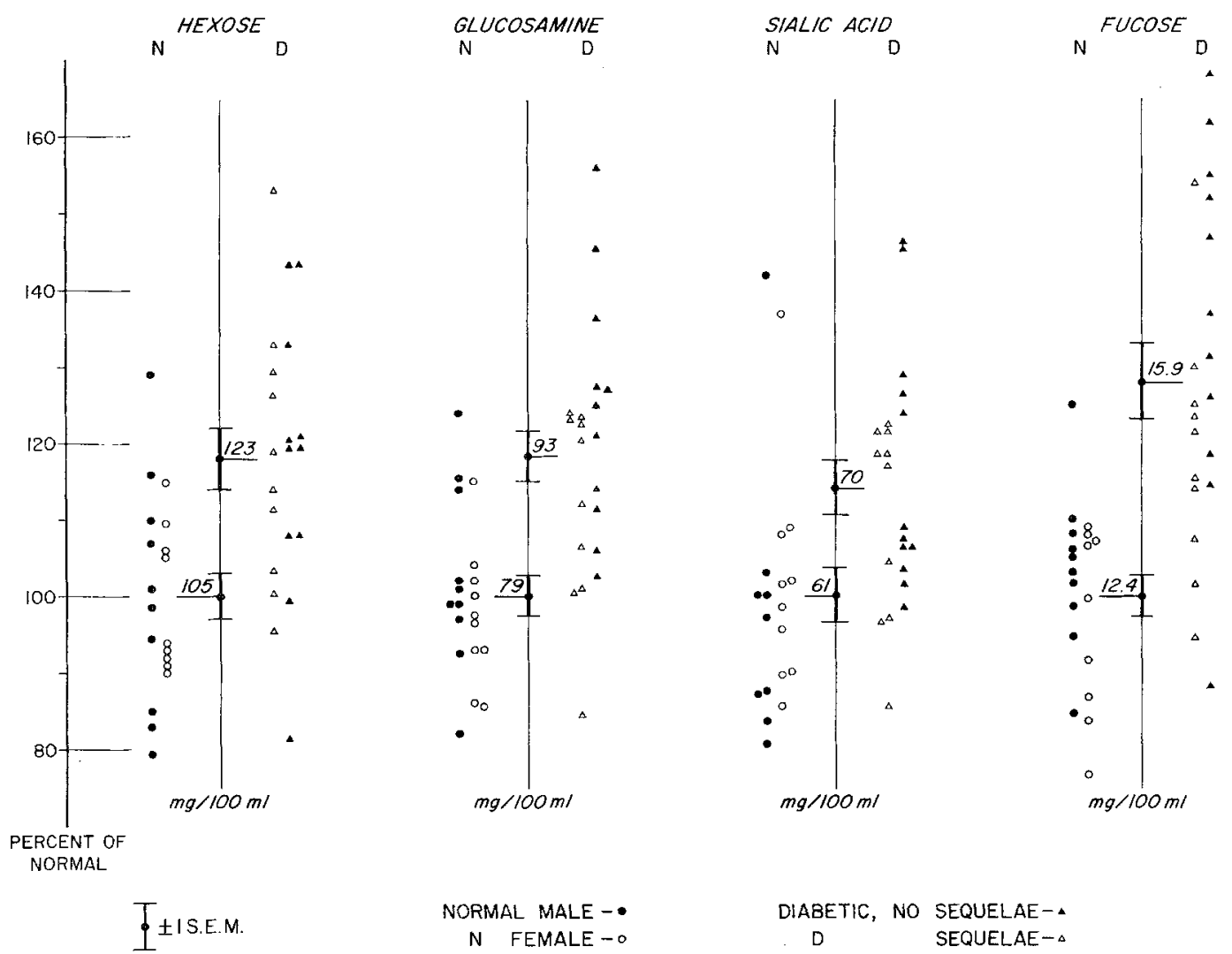

Fig. 1. Comparison of levels of various protein-bound carbohydrates between normal and diabetic subjects. The left hand scale shows that all points were plotted as percent difference from mean normal value to show variation on a comparable scale and to show the degree of elevation in the diabetic subjects. The numbers in the centre of each standard error bracket are the mean values for the appropriate carbohydrate, control values on the left and diabetic on the right of each vertical line. The normal subjects (circles) are distinguished on the basis of sex and the diabetics (triangles) on the basis of presence or absence of clinically evident small blood vessel disease

Table 3. Correlation Coefficients Between Protein-Bound Carbohydrate Groups

\begin{tabular}{|c|c|c|c|c|c|c|c|c|}
\hline \multicolumn{4}{|c|}{ Controls } & & \multicolumn{4}{|c|}{ Diabetics } \\
\hline Hexose & Glucosamine & Sialic acid & Fucose & & Hexose & Glucosamine & Sialic acid & Fucose \\
\hline- & $+0.65^{b}$ & +0.26 & $+0.78^{\mathrm{b}}$ & Hexose & - & $+0.68^{\mathrm{b}}$ & $+0.57^{\mathrm{a}}$ & $+0.53^{\mathrm{a}}$ \\
\hline$+0.65^{b}$ & - & +0.07 & $+0.61^{\mathrm{b}}$ & Glucosamine & $+0.68^{b}$ & - & $+0.73^{b}$ & $+0.72^{b}$ \\
\hline+0.26 & +0.07 & & +0.23 & Sialic acid & $+0.57^{a}$ & $+0.73^{b}$ & $-06 b^{b}$ & $+0.64^{\mathrm{b}}$ \\
\hline$+0.78^{b}$ & $+0.61^{\mathrm{b}}$ & +0.23 & - & Fucose & $+0.03^{\mathrm{d}}$ & $+0.12^{0}$ & $+0.64^{0}$ & - \\
\hline
\end{tabular}

Values given are calculated as $\mathrm{r}$ and the significance determined using standard tables [13].

a $P<0.05$

b $P<0.01$

or below the mean of the control group, so that both variation in the control and diabetic groups and the degree of elevation in diabetes are clearly illustrated. Relative mean elevation is greatest for fucose and least for sialic acid. Variation, usually slightly greater in the diabetic group, was significantly different only for fucose $(F=3.5, P<0.01)$.

The levels of some types of protein-bound carbohydrates were found to be closely related to each other in both the control and diabetic groups. All four protein-bound carbohydrate values were in the normal range in six of the twenty-one diabetics. Correlation between types of protein-bound carbohydrate in control and diabetic subjects is given in Table 3. High correlations were found in both groups with one exception. Very low correlations were present between sialic acid levels and the level of other protein-bound carbohydrates in the control group, but similar correlations were high in the diabetic group.

Erythrocyte sedimentation rate tended to be elevated with great frequency in the diabetic group even though acute infection had been excluded. Mean sedi- 
mentation rate was 23 both for the diabetics with and without sequelae. To ascertain the effect of sedimentation rate on protein-bound carbohydrate levels the mean percent elevation of protein-bound carbohydrate was determined on the ten diabetics (six with sequelae) with sedimentation rate less than $20 \mathrm{~mm}$ per hour. Comparison of the subgroup of ten diabetics with sedimentation rate less than $20 \mathrm{~mm}$ per hour with the entire diabetic group revealed a less striking elevation of protein-bound carbohydrate when the sedimentation rate was lower. Whereas the total diabetic group showed percent elevation above mean normal value of $18 \%$ for hexose, $18 \%$ for glucosamine, $14 \%$ for sialic acid, and $28 \%$ for fucose (Fig. 1), the elevation of low sedimentation rate diabetics was $10 \%$ for hexose, $11 \%$ for glucosamine, $10 \%$ for sialic acid, and $19 \%$ for fucose.

Increase in alpha 2-macroglobulin and proteinbound carbohydrate levels was studied further by comparing diabetics with and without recognizable atherosclerotic disease. When the two female values were adjusted to male values by subtracting 70 , the mean alpha 2-macroglobulin level in the eight diabetic subjects with known atherosclerosis was $354 \pm 76 \mathrm{mg} /$ $100 \mathrm{ml}$, while the mean value for the twelve diabetics not so afflicted was $272 \pm 83 \mathrm{mg} / 100 \mathrm{ml}$, the normal male value being $265 \pm 55 \mathrm{mg} / 100 \mathrm{ml}$. The alpha 2-macroglobulin levels were studied in relation also to duration of the disease. The correlation coefficient, $r=+0.31$, did not differ significantly from zero. The mean hexose, glucosamine, sialic acid and fucose values were also determined on the diabetics grouped for presence or absence of atherosclerosis. The nine diabetics with atherosclerosis had a mean percent elevation of $20 \%$ for hexose, $24 \%$ for glucosamine, $17 \%$ for sialic acid, and $36 \%$ for fucose, whereas the twelve without clinical evidence of atherosclerosis had a mean percent increase of $16 \%$ for hexose, $14 \%$ for glucosamine, $12 \%$ for sialic acid, and $22 \%$ for fucose, retaining the pattern found in the entire diabetic group. No difference in degree of elevation of alpha 2-macroglobulin or protein-bound carbohydrate could be found when the seven diabetics with borderline or elevated blood pressures were compared with the fourteen normotensive diabetics.

The diabetic group data showed some interesting relationships when the association of findings was studied using rank order correlation. Alpha 2-globulin level was found to be related to duration of diabetes $(R=+0.51, P<0.05)$, but the level of different types of protein-bound carbohydrates showed no such relationship. The reduction of total protein was related to the level of serum albumin $(R=+0.62, P<0.01)$. Serum albumin also declined with age $(R=+0.55$, $P<0.02)$. A correlation was found between plasma glucose and the alpha 2 -globulin level $(R=+0.48$, $P<0.05$ ), but glucose level could not be related to any other variable including any protein-bound carbohydrate. Alpha 2-globulin level was found to be related to its largest component, alpha 2-macroglobulin $(R=$ $+0.65, P<0.05)$.

\section{Discussion}

The group of diabetics studied appeared representative of the diabetic population of the U.S., except for male preponderance, an effect of the sex distribution of the total hospital patient population. The mean age of 59 years is close to the diabetic mean age of 60 years [3] and the treatment pattern corresponds to the proportion treated by diet alone, oral agents, and insulin in the U.S. diabetic population [3]. The incidence of heart disease was higher than in diabetics generally $(21.1 \%)[3]$, but may reflect a higher detection rate arising from regular examination by electrocardiogram.

The existence of altered levels of protein electrophoretic components in diabetes mellitus has been demonstrated by many investigators in past reports, and our data are quite consistent with the majority of such reports. Depression of serum albumin in the absence of proteinuria has been found almost universally $[33,17$, $15,41,7]$, and is usually associated with a significant decline in total serum protein level $[17,41]$. The albumin level is also usually lower when clinically recognizable retinopathy or neuropathy is present, but the effect is seen in diabetics without evident sequelae [33, $17,15,41,7]$. Although some decline of albumin in our diabetic group was related to age as shown by the negative correlation between age and albumin level in the diabetic group, decrease in serum albumin concentration has been found in diabetic schoolchildren by Sterky and Böttiger [41,7] suggesting that diabetes is the more important factor.

Many investigators have noted a rise in the alpha 2-globulin level in diabetes, but reports have differed in whether such elevations are present in all diabetic groups, even those without sequelae $[33,17,15,38]$ or only in diabetics with sequelae $[26,21]$. A possible explanation of this conflict and the normal alpha 2-globulin levels found in diabetics without sequelae in this study is suggested by correlation studies. A relationship between alpha 2-globulin level and both fasting plasma glucose and duration of disease was found, in agreement with the tentative conclusions of Ejarque et al. [17]. A group of diabetics without sequelae whose control was poor or whose disease was of long duration would be expected to have a higher alpha 2-globulin level.

There was a general tendency for diabetics to show greater than normal variation in all electrophoretically determined serum protein fractions. This tendency is more striking in adults [17] than in children, [41], and was statistically significant only for the gamma-globulin fraction in this study.

Previous investigators have usually measured only one or two types of protein-bound carbohydrate in adult diabetics, hexose or hexosamine or both. The 
degree of elevation has often been greater than that found in this study $[21,40,20]$, often about the same $[26,12,43,24,2]$, and occasionally less $[1,30,5]$. Many investigators who had divided diabetics into those with and without sequelae, often using criteria widely differing from ours have found lower hexose and hexosamine in diabetics without sequelae $[21,2,1,30,5]$, but others have found more comparable values $[26,12$, $43,24]$. It is suggested that subject selection played a role in these findings. In an excellent study of proteinbound carbohydrate levels (hexose, hexosamine, and sialic acid) in diabetic schoolchildren [41] compared with normal schoolchildren [7], Sterky and Böttiger found rather smaller rises in protein-bound carbohydrate levels than are usually reported in adults, $13 \%$ for hexose, $5 \%$ for hexosamine, and $8 \%$ for sialic acid. For comparison, the elevations in this study were $18 \%$ for hexose, $18 \%$ for glucosamine, and $14 \%$ for sialic acid. At first glance, this might suggest that age is a factor in producing the elevation and a small contribution by age cannot be excluded but, except for a slight increase in sialic acid content, no age-related changes have been found in normal men [8] and women [9] from the third to the ninth decade, nor were any differences found between sexes. Elevated sedimentation rate, rather than age, appears to be associated with higher proteinbound carbohydrate levels in diabetics. In the study on children, subjects with a sedimentation rate greater than $20 \mathrm{~mm} / \mathrm{h}$ were eliminated, even though no apparent cause for the elevation was present. When such a criterion is applied to the adult subjects in this study the elevations of the remaining diabetics were $10 \%$ for hexose, $11 \%$ for glucosamine, and $10 \%$ for sialic acid, rather comparable with the diabetic children. The fucose elevation remained disproportionately high, being $19 \%$. It appears reasonable to conclude that the magnitude of the protein-bound carbohydrate elevation found may be influenced by disorders which affect the sedimentation rate, whether closely related to diabetes or not, which are more frequently seen in adult diabetics. A disorder fitting this concept is atherosclerosis. Prior studies in diabetics have shown that protein-bound hexose [18] and hexosamine [35] were higher in the presence of atherosclerosis. In the present study, protein-bound carbohydrate elevation was about $50 \%$ greater in diabetics with atherosclerosis than in diabetics without atherosclerosis, but the disproportionate elevation of fucose does not appear related to atherosclerosis. As already suggested by the data of Cleve et al. [12], much of the difference in protein-bound carbohydrate levels in our diabetics with and without atherosclerosis is accounted for by alpha 2-macroglobulin, which was $30 \%$ higher in the former group than the latter whose mean level was essentially normal.

No effect of the development of small vessel disease on the protein-bound carbohydrate level was found despite elevation of alpha 2-globulin levels in the group with sequelae nor was the level of protein-bound carbo- hydrate related to the level of any electrophoretic fraction.

Several investigators have reported increased levels of individual serum glycoproteins in diabetes. Haptoglobin $[4,19]$, alpha 2-macroglobulin $[23,11,19]$, alpha 1-antitrypsin [19], Gc-globulin [11], alpha 1-acid glycoprotein [11] and haemopexin [11] have been reported to be elevated. The degree of elevation is usually mild, and in the case of haptoglobin related to the presence of sequelae. We have calculated the contribution to protein-bound carbohydrate increase which might be attributed to increased concentrations of these glycoproteins, using reported carbohydrate contents [34]. The protein-bound carbohydrate elevation produced would be $9 \%$ for hexose, $8 \%$ for glucosamine, $10 \%$ for sialic acid, and $3 \%$ for fucose. The increases actually found in our twenty-one diabetics were $18 \%$ for hexose, $18 \%$ for glucosamine, $14 \%$ for sialic acid, and $28 \%$ for fucose. The degree of elevation of fucose may be contrasted with the patterns of elevation found in tuberculosis, subacute bacterial endocarditis, and cancer by Winzler [47] and in schizophrenia by Seal [36], where fucose is much less elevated than other protein-bound carbohydrates, especially sialic acid. The only pattern bearing any similarity to that in this study was that seen by Winzler in liver disease [42], where the serum protein disturbance is dominated by elevation of the beta and gamma components [20], due to an increase in immune globulins, which have a high fucose content [34]. In our diabetic group the gamma-globulin levels were not increased, and a cause other than immune globulin elevation must be considered. The pattern of elevation appears sufficiently different from other patterns reported to be designated distinctive to diabetes mellitus.

Correlation studies between types of protein-bound carbohydrate, not reported before, illustrate what might be expected from knowledge of protein-bound carbohydrate composition of individual serum glycoproteins [34]. Most serum glycoproteins contain all four types of carbohydrate, but in somewhat differing ratios. Most variable are sialic acid and fucose, the former being high in alpha-globulins and low in gammaglobulins, and the latter the opposite. The levels of individual alpha-globulins tend to vary much more widely than gamma-globulin, apparently causing the low correlation between sialic acid and the other protein-bound carbohydrates in the control group. In the diabetic group, high correlations between different types of protein-bound carbohydrate, including sialic acid, were found even though quite variable levels of different serum proteins were present. The elevation of protein-bound carbohydrate is clearly not due to random increases in glycoproteins which differ widely in carbohydrate composition. Either a modification of glycoprotein carbohydrate composition in diabetes, or elevation of one protein or a group of proteins with rather similar carbohydrate composition, and higher in fucose than the "average" glycoprotein would 
explain the observed correlations. Since no correlation could be found between the level of protein-bound carbohydrate and the blood sugar level or duration of diabetes, it is unclear whether the protein-bound carbohydrate increase is induced by the diabetic state or precedes it and whether it is modified by controlling the diabetic state.

In conclusion, this study demonstrates changes in serum proteins and protein-bound carbohydrates in diabetics. The magnitude of such changes is affected by factors other than diabetes, and in no case are the diabetic and normal ranges fully separated. The changes in albumin and alpha 2 -globulin level appear to be induced by the diabetic state, but the change in protein-bound carbohydrate, due to a more subtle disturbance of the serum proteins, is not clearly induced by diabetes. The protein-bound carbohydrate change requires further examination since neither the magnitude nor the pattern of elevation is explained by current knowledge of glycoprotein composition and concentration in diabetes.

Acknowledgements: The author wishes to express his thanks for technical assistance to Miss Janet Webb and Mrs. Jean Sauer and to Drs. C.A. Domz and L. L. Sparks for their critical review of the manuscript. The continuing encouragement and help of Dr. Peter H. Forsham has made the completion of this study possible. This study was supported by U.S. Public Health Service, National Institutes for Arthritis and Metabolic Diseases Grant AIM-9677-02 and Divison of Hospitals Grant M67-10-64, and by the Doris Fay Palmer Fund for Diabetes Research.

\section{References}

1. Adlersberg, D., Wang, C.-I., Rifkin, H., Berkman, J., Ross, G., Weinstein, C.: Serum lipids and polysaccharides in diabetes mellitus. Diabetes 5, 116-120 (1956).

2. Andreani, D.V., Gray, C.H.: Serum polysaccharides in diabetes mellitus. Clin. ehim. Acta 1, 7-15 (1956).

3. Bauer, M.L.: Characteristics of persons with diabetes, p. $1-48$. Washington, D.C.: U.S. Department of Health, Education and Welfare 1967.

4. Bergstrand, C.G., Fürst, P., Larsson, Y., Sterky, G.: Serum haptoglobin in juvenile diabetes. Scand. J. clin. Lab. Invest. 14, 629-632 (1962).

5. Berkman, J., Rifkin, H., Ross, G.: The serum polysaccharides in diabetic patients with and without degenerative vascular disease. J. clin. Invest. 32, $415-421(1953)$.

6. Bierry, H., Rathery, F.: Diabète et glycémie. C.R. Acad. Sci. 172, 244-246 (1921).

7. Böttiger, L.E., Sterky, G.: Serum proteins and glucoproteins in normal schoolchildren. Acta med. scand. 172, 339-342 (1962).

8. - Carlson, L.A. : Serum glucoprotein concentrations in normal men. Clin. chim. Acta 5, 664-671 (1960).

9. - Hölmstrom, A. : Serum protein-bound carbohydrates in normal women. J. Lab. clin. Med. 63, 772-775 (1964).

10. Camerini-Davalos, R.A.: Diagnosis of early asymptomatic diabetes. New York State J. Med. 66, 16361642 (1966).

11. Cleve, H., Alexander, K., Mitzkat, H.J., Nissen, P., Salzmann, I.: Serumglykoproteine beim Diabetes mellitus; quantitative immunologische Bestimmung von saurem $\alpha_{1}$-Glykoprotein, Gc, $\alpha_{2}$-Makroglobulin und Hämopexin bei Diabetikern mit und ohne Angiopathien. Diabetologia 4, 48-55 (1968).

12. Cogan, D.C., Merola, L., Laibson, P.R. : Blood viscosity, serum hexosamine and diabetic retinopathy. Diabetes 10, 393-395 (1961).

13. Diem, K.: Documenta Geigy Scientific Tables, 6th edition, Ardsley. New York: Geigy Pharmaceuticals 1962.

14. Dische, Z., Shettles, L.B.: A specific color reaction of methylpentoses and a spectrophotometric micromethod for their determination. J. biol. Chem. 175, $595-603(1948)$.

15. Ditzel, J., Moinat, P.: Changes in serum proteins, lipoproteins, and protein-bound carbohydrates in relation to pathological alterations in the microcircula. tion of diabetes subjects. J. Lab. clin. Med. 54, 843 859 (1959).

16. Dubois, M., Gilles, K.A., Hamilton, J.K., Rebers, P. A., Smith, F.: Coloximetric method for determination of sugars and related substances. Analyt. Chem. 28, $350-356(1956)$.

17. Ejarque, P., Marble, A., Tuller, E. F.: Proteins, lipoproteins and protein-bound carbohydrates in the serums of diabetic patients. Amer. J. Med. 27, 221-230 (1959).

18. Fry, I.K., Trounce, J.R., Cook, C.A.G.: Vascular disease in diabetes mellitus. Diabetes 8, 174-178 (1959).

19. Ganrot, P.O., Gydell, K., Ekelund, H.: Serum concentrations of $\alpha_{2}$-macroglobulin, haptoglobin and $\alpha_{1}$ antitrypsin in diabetes mellitus. Acta endocr. 55, $537-544(1967)$.

20. Heiskell, C.L., Carpenter, C.M., Weimer, H. E., Nakagawa, S.: Serum glycoproteins in infectious and inflammatory diseases. Ann. N.Y. Acad. Sci. 94, 183209 (1961).

21. Introzzi, P., Bernasconi, C., Buscarini, L.: Serum proteins, lipids and protein-bound carbohydrates in vascular complications of diabetes mellitus. Acta med. scand. 160, $47-58(1958)$.

22. Jacubeit, M., Brünger, P., Knedel, M. : Untersuchungen über den Gehalt an fucose im serum und in proteinfraktionen. Klin. Wschr. 37, 460-464 (1959).

23. James, K., Johnson, G., Fudenberg, H.H.: The quantitative estimation of $\alpha_{2}$-macroglobulin in normal, pathological and cord sera. Clin. chim. Acta 14, 207-$214(1966)$

24. Keiding, N.R., Tuller, E.F.: Protein-bound carbohydrate in the serum of diabetic patients with and without vascular complications. Diabetes 4, 37-43 (1955).

25. Kingsley, G.R.: The determination of serum total protein, albumin, and globulin by the biuret reaction. J. biol. Chem. 131, 197-200 (1939).

26. Lerman, S., Pogell, B. M., Lieb, W.: Serum proteins and total glucosamine in diabetic retinopathy and glomerulosclerosis. Arch. ophthal. 57, 354-360 (1957).

27. Levvy, G.A., McAllan, A.: The N-acetylation and estimation of hexosamines. Biochem. J. 73, 127-132 (1959).

28. MoMillan, D.E., Sauer, J.H., Forsham, P.H.: Problems in the determination of serum fucose in diabetes mellitus. Metabolism 17, $105-107$ (1968).

29. - Breithaupt, D.L., Rosenau, W., Lee, J.C., Forsham, P.H.: Forearm skin capillaries of diabetic, potential diabetic and nondiabetic subjects. Diabetes 15, $251-257(1966)$.

30. Nielsen, G.H., Poulsen, J.E.: The protein-bound carbohydrates in serum from diabetic patients and the relation to the duration of diabetes and the vaseular complications. Rep. Steno. Mem. Hosp. Nord. Insulin Lab 5, 71-93 (1953).

31. Saifer, A., Weintraub, S.K.: Serum protein-bound fucose levels in certain chronic diseases. Clin. chim, Acta 6, 174-180 (1961). 
32. Scherr, G.H.: Cellulose acetate electrophoresis in microbiology and immunology. Trans. New York Acad. Sci. 23, 519-530 (1961).

33. Schertenleib, F., Tuller, E. F.: Paper electrophoresis of serum proteins in diabetic patients. Diabetes $\mathbf{7}$, $46-52(1958)$.

34. Schultze, H.E., Heremans, J.F. : Molecular Biology of Human Proteins, Vol. I, 182-227. New York: Elsevier 1966.

35. Schwartz, C.J., Gilmore, H.R.: Effect of atherosclerosis and age upon the serum mucoprotein and hexo. samine levels in man. Circulation 18, 191- 195 (1958).

36. Seal, U. S., Eist, H. : Elevation of serum protein-bound carbohydrates and haptoglobin in schizophrenia. Clin. Chem. 12. $709-716$ (1966).

37. Shaw, R.A., Kryston, L.J., Mills, L.C.: Plasma fucose and fucose tolerance in diabetes mellitus. Ann. N.Y. Acad. Sci. 148, $787-795$ (1968).

38. Skanse, B.: The serum proteins in diabetes mellitus in relation to vascular complications. Acta endocr. 43, $3-11$ (1963).

39. Spiro, R.G.: Glycoproteins and diabetes. Diabetes 12, $223-230(1963)$.

40. Stary, Z., Bursa, F., Kaleoglu, Ö., Bilen, M.: Kan serumunda bulunan proteinlere bagli karbonhidrat hakkinda. M. Bull. Fac. med. Istanbul 13, 453-465 (1950).
41. Sterky, G., Böttiger, L.E.: Serum proteins and glucoproteins in diabetic schoolchildren. Acta med. scand. 172, 343-350 (1962).

42. Svennerholm, L.: Quantitative estimation of sialic acids. III. An anion exchange resin method. Acta chem. scand. 12, 547-554 (1958).

43. Törnblom, N., Nordström, K. : Serum polysaccharides and hyaline vascular changes in diabetes mellitus. Acta endocr. 17, 426-431 (1954).

44. Warren, L.: The thiobarbituric acid assay of sialic acids. J. biol. Chem. 234, $1971-1975$ (1959).

45. Weiden, S.: Serum hexosamine levels in health and disease. J. clin. Path. 11, 177-182 (1958).

46. Winzler, R.J.: Plasma glycoproteins and mucopolysaccharides. In Small Blood Vessel Involvement in Diabetes Mellitus, p. 235-242. Washington, D.C.: American Institute of Biological Sciences 1964.

47. Winzler, R.J.: Determination of serum glycoproteins. Methods of Biochemical Analysis 2, 279-310 (1955).

48. Webster, D.: A simple method of serum protein fractionation on cellulose acetate and a comparison of the albumin levels with a method of sodium sulphite fractionation. Clin. chim. Acta 11, 101-112 (1965).

Donald E. McMillan

Sansum Clinic Research Foundation

Santa Barbara,

California, USA 